\title{
Increased Expression of Toll-like Receptors in Aseptic Loose Periprosthetic Tissues and Septic Synovial Membranes Around Total Hip Implants
}

\author{
YASUNOBU TAMAKI, YUYA TAKAKUBO, KAORU GOTO, TOMOYUKI HIRAYAMA, KAN SASAKI, \\ YRJÖ T. KONTTINEN, STUART B. GOODMAN, and MICHIAKI TAKAGI
}

ABSTRACT. Objective. Toll-like receptors (TLR) are transmembrane proteins found in various cells. They recognize infectious and endogenous threats, so-called danger signals, that evoke inflammation and assist adaptive immune reactions. It has been suggested that TLR play a role in periprosthetic tissues and arthritic synovium. Our objective was to elucidate tissue localization and functional roles of TLR in periprosthetic tissues in 2 different pathologic conditions, aseptic and septic implant loosening.

Methods. For immunohistochemistry studies, aseptic synovial-like membranes of periprosthetic connective tissues $(n=15)$ and septic synovial capsular tissues $(n=5)$ were obtained at revision surgery and from salvage of infected totally replaced hips, respectively. Osteoarthritic synovial tissues were used for comparison $(n=5)$. Samples were processed for immunohistopathologic analyses for tissue colocalization of TLR with CD68 and/or CD15 using the Alexa fluorescent system. Total RNA was isolated from frozen tissues and converted into cDNA, TLR 2, 4, 5 and 9 sequences were amplified, and the products were quantified using real-time polymerase chain reaction.

Results. Immunofluorescent staining showed colocalization of TLR 2, 4, 5, and 9 with CD68 in the focal monocyte/macrophage aggregates in aseptic synovial-like membranes from loose total hip replacements. TLR 2, 4, 5, and 9 were also found colocalized with CD15+ polymorphonuclear leukocytes and CD68+ mononuclear cells of the synovial membranes from septic total hip replacements. In osteoarthritic synovial tissues, expression of TLR was found only in vascular cells and mononuclear cells, and the reactivity was weak. mRNA levels of TLR 2, 4, 5, and 9 were increased in both aseptic and septic periprosthetic tissues. TLR 2 and 5 were significantly higher than TLR 4 and 9 in aseptic and septic samples.

Conclusion. Peri-implant tissues were well equipped with TLR in both aseptic and septic conditions. TLR 2- and TLR 5-mediated responses seemed to dominate. In aseptic loosening, monocytes/ macrophages were the main TLR-equipped cells apparently responsible for alarmin-induced responses. This could lead to production of inflammatory cytokines and extracellular matrix-degrading proteinases after phagocytosis of wear debris derived from an implant, but in septic cases they eventually respond to microbial components. Thus, inflammatory cells in both aseptic and septic tissues were equipped with TLR, providing them with responsiveness to both endogenous and exogenous TLR ligands. (First Release Feb 1 2009: J Rheumatol 2009;36:598-608; doi:10.3899/ jrheum.080390)

Key Indexing Terms:

TOLL-LIKE RECEPTORS

ASEPTIC TISSUES

SEPTIC TISSUES

TOTAL HIP REPLACEMENT HOST REACTION

From the Department of Orthopaedic Surgery and Department of Anatomy and Cell Biology, Yamagata University School of Medicine, Yamagata, Japan; Institute of Biomedicine, Department of Anatomy, University of Helsinki, Helsinki; Department of Medicine/Invärtes medicin, Helsinki University Central Hospital, Helsinki; ORTON Orthopaedic Hospital of the Invalid Foundation, Helsinki; and COXA Hospital for Joint Replacement, Tampere, Finland; and Department of Orthopaedic Surgery, Stanford University, Stanford, California, USA.

Supported by a Grant-in-Aid for Scientific Research, the Ministry of Science and Culture of Japan (C2-17591546), and Yamagata Health Support Society for the Promotion of Science 2006-2008, Japan; and the National Group of Excellence (the Academy of Finland), PhD Graduate School (Ministry of Education), Sigrid Jusélius Foundation, and the HUS evo program, Finland.

Y. Tamaki, MD, PhD; Y. Takakubo, MD, PhD, Department of Orthopaedic
Surgery; K. Goto, MD, PhD, Department of Anatomy and Cell Biology; T. Hirayama, MD; K. Sasaki, MD, PhD, Department of Orthopaedic Surgery, Yamagata University School of Medicine; Y.T. Konttinen, MD, PhD, Institute of Biomedicine, Department of Anatomy, University of Helsinki, Department of Medicine/Invärtes medicin, Helsinki University Central Hospital, ORTON Orthopaedic Hospital of the Invalid Foundation, COXA Hospital for Joint Replacement; S.B. Goodman, MD, PhD, Department of Orthopaedic Surgery, Stanford University; M. Takagi, MD, PhD, Department of Orthopaedic Surgery, Yamagata University School of Medicine.

Address reprint requests to Dr. Y. Tamaki, Department of Orthopaedic Surgery, Yamagata University School of Medicine, 2-2-2 Iida Nishi, Yamagata 990-9585, Japan. E-mail: ytamaki@med.id.yamagata-u.ac.jp Accepted for publication October 8, 2008.

Personal non-commercial use only. The Journal of Rheumatology Copyright $\subset$ 2009. All rights reserved. 
Total hip replacement (THR) is a procedure that reliably provides pain relief and improves daily activity for patients with destructive endstage hip joint disease. The main longterm complication of THR surgery is prosthetic loosening, often combined with osteolysis ${ }^{1,2}$. The causes of loosening are roughly divided into 2 categories. One is so-called aseptic loosening and the other the septic loosening caused by implant infection. Aseptic loosening is caused in part by foreign-body inflammation in response to wear debris, formed as a result of adhesive and abrasive wear ${ }^{3-6}$ and by delayed-type hypersensitivity reaction against self modified by metal ions formed as a result of corrosion ${ }^{2,6}$. Monocytes/macrophages observed in synovial-like membranes play an important role in the aseptic periprosthetic loosening/osteolysis, although the receptors involved have not been characterized in detail ${ }^{7}$. It is well known that enhanced production of osteolytic inflammatory cytokines and extracellular matrix-degrading proteinases are produced as a result of phagocytosis of wear particles, but other ligand receptor-mediated events might also play a role. In contrast to aseptic loosening, polymorphonuclear cells are relatively prominent in septic loosening ${ }^{5,8-13}$. In a pilot study we demonstrated toll-like receptor (TLR) 4 and 9 expression as part of the innate immune response that also provides the second signal to the adaptive immune responses in monocyte/macrophage-rich interfacial synovial-like membranes of aseptic loose THR implants ${ }^{14}$. However, their expression in septic loosening and eventual differences between aseptic and septic loosening are unclear ${ }^{15}$.

Monocytes/macrophages, polymorphonuclear cells, and dendritic cells play a central role in the innate system. Monocyte/macrophages and polymorphonuclear cells can phagocytose foreign bodies, and protect the host from microbial attacks. Their prompt reaction forms the first-line defense, but is relatively nonspecific, as the repertoire of TLR is quite limited compared to those mediated by $\mathrm{T}$ cell receptors and immunoglobulins ${ }^{16-18}$.

Toll receptor was originally identified in Drosophila ${ }^{19,20}$. Later, a mammalian Toll homolog, TLR 4, was reported ${ }^{21}$. Since then it has become clear that TLR are essential agents in the recognition of microbial [i.e., pathogen associated molecular patterns (PAMP), dead or alive] and endogenous (alarmins) signals that together form the so-called "danger signals." Endogenous alarmins and exogenous PAMP can be considered subgroups of a larger set, the damage associated molecular patterns (DAMP) ${ }^{22}$. DAMP stimulate inflammatory responses via TLR, but also provide the danger signal to adaptive immune responses. TLR2, 4, and 5 are expressed on the cell surface. Bacterial lipoproteins are recognized by TLR 2, lipopolysaccharide by TLR 4, flagellin (bacterial flagella) by TLR 5, and fungal zymosan by TLR 2 as exogenous ligands. In contrast, TLR 9 is expressed in endosomal components that can recognize unmethylated $\mathrm{CpG}$ deoxyribonucleic acid (bacterial DNA), as exogenous lig- ands ${ }^{16,23,24}$. TLR can recognize not only exogenous ligands of microbial origins, but also endogenous ligands derived from self-components. For example, TLR2 recognizes heat shock protein (HSP) 60, 70, and gp96. TLR4 recognizes HSP 60, 70, gp96, fibronectin 7EDA domain, and oligosaccharides of hyaluronan. TLR9 recognizes chromatin-IgG complexes ${ }^{25}$. After recognition of DAMP, TLR trigger intracellular signaling pathways that result in the induction of inflammatory cytokines, type I interferon, and chemokines. Moreover, signaling from TLR induces the upregulation of costimulatory molecules such as myeloid differentiation primary response protein 88 (MyD88), MyD88-adapter like (Mal) or Toll/interleukin 1 receptor (TIR) domain-containing adapter protein (TIRAP), TIR domain-containing adapter inducing interferon- $\beta$ (TRIF) or TIR-containing adaptor molecule-1 (TICAM-1), TRIF-related adapter molecule (TRAM) or TIR-containing adaptor molecule-2 (TICAM-2), and sterile alpha and HEAT-Armadillo motifs $(\mathrm{SARM})^{26}$. The signaling is essential for the induction of pathogen-specific adaptive immune responses, thus indicating that TLR link innate and adaptive immunity (Figure $1)^{27,28}$. Our previous report of the presence of TLR in aseptic periprosthetic tissues suggested enhanced responsiveness of the synovial-like interface membrane to TLR ligands ${ }^{14}$.

We investigated 4 important TLR to elucidate their presence in septic loosening and to determine if there are any differences between the aseptic and septic loosening.

\section{MATERIALS AND METHODS}

Patients and samples. Fifteen samples of the synovial membrane-like interface tissues between bone and implant and the inner regenerated capsular tissues of loosened hip prostheses were obtained at revision total hip arthroplasty performed for aseptic loosening. Thirteen patients were women and 2 were men, with a mean age of 70.4 years (range 55-82 yrs). Five total hip surgeries were originally performed due to primary osteoarthritis (OA), and 10 to treat secondary OA caused by congenital dislocation of the hip joint. The mean time from primary arthroplasty to revision was 15.3 years (Table 1). Erythrocyte sedimentation rate (ESR) and/or C-reactive protein (CRP) levels were within normal limits in all patients. All samples were negative for bacterial and fungal cultures. Five samples of the infectious synovial membrane were collected from late implant-related infections of total hip prostheses ( 3 female patients, 2 male; mean age 64 yrs, range 51-79). The mean time from primary arthroplasty to revision was 6 years. Type of bacterial species identified from tissue culture was coagulase-negative Staphylococci in 2 cases, S. epidermidis, S. aureus, and Escherichia coli in one case (Table 2). Neutrophilic filtration was histologically identified, indicating peri-implant infection by detection of more than 5 neutrophils per high-power field at a magnification of $\times 400^{29}$. As controls, 5 synovial samples were collected from patients with secondary OA due to hip dysplasia undergoing primary total hip arthroplasty ( 3 female patients, 2 male; mean age 74.0 yrs, range 69-81). None of the patients had had episodes of inflammatory arthritis. All control samples were negative in bacterial and fungal cultures and had normal ESR or CRP at the surgery. Samples were embedded in OCT (Lab-Tek, Elkhart, IN, USA) for immunostaining and snap-frozen for ribonucleic acid (RNA) extraction and stored at $-80^{\circ} \mathrm{C}$.

The study protocol was approved by the ethical committee of Yamagata University School of Medicine.

Histopathological examinations. Blocks from all samples were fixed in $4 \%$

Personal non-commercial use only. The Journal of Rheumatology Copyright (C) 2009. All rights reserved. 


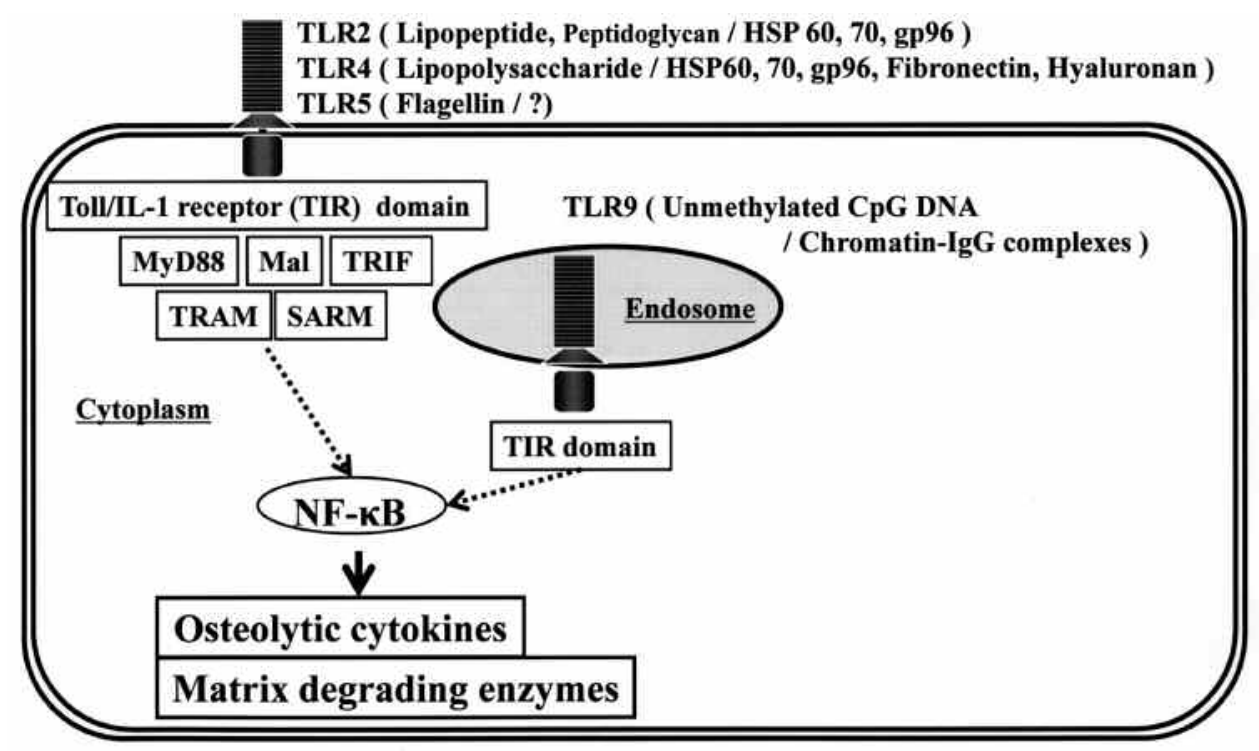

Figure 1. TLR-related signal pathways and their ligands (exogenous PAMP/endogenous alarmins). Not only exogenous PAMP (e.g., bacterial lipopeptide, lipopolysaccharide, and flagellin), but also endogenous alarmins (HSP 60, HSP 70, gp96, fibronectin, hyaluronan, and chromatin-IgG complexes) have potential to be recognized as TLR ligands, leading to production of osteolytic cytokines and extracellular matrixdegrading proteinases. This cascade may contribute to the pathogenesis of aseptic loosening/osteolysis.

Table 1. Profile of revision patients.

\begin{tabular}{lccccccc}
\hline Case & Diagnosis & Age/sex & $\begin{array}{c}\text { Years from THR } \\
\text { to Revision }\end{array}$ & $\begin{array}{c}\text { Type of } \\
\text { Prosthesis }\end{array}$ & Type of Alloy & Wear & $\begin{array}{c}\text { Black } \\
\text { Particles }\end{array}$ \\
\hline 1 & SOA & $71 \mathrm{~F}$ & 19 & Six-Ti & TiA16V4 & + & - \\
2 & POa & $69 \mathrm{~F}$ & 24 & Charnley & stainless & - & - \\
3 & SOA & $72 \mathrm{M}$ & 15 & Six-Ti & TiA16V4 & - & - \\
4 & SOA & $64 \mathrm{~F}$ & 10 & YU & TiA16V4 & + & - \\
5 & SOA & $67 \mathrm{~F}$ & 17 & Bateman & CoCrMo & - & - \\
6 & POA & $74 \mathrm{~F}$ & 10 & YU & TiA16V4 & + & - \\
7 & SOA & $55 \mathrm{~F}$ & 20 & Six-Ti & TiA16V4 & - & - \\
8 & POA & $82 \mathrm{~F}$ & 19 & Six-Ti & TiA16V4 & - & - \\
9 & POA & $82 \mathrm{~F}$ & 12 & YU & TiA16V4 & + & - \\
10 & POA & $80 \mathrm{M}$ & 9 & YU & TiA16V4 & - & - \\
11 & SOA & $71 \mathrm{~F}$ & 19 & Six-Ti & TiA16V4 & - & - \\
12 & SOA & $63 \mathrm{~F}$ & 9 & YU & TiA16V4 & + & - \\
13 & POA & $78 \mathrm{~F}$ & 26 & Muller & CoCrMo & - & - \\
14 & SOA & $72 \mathrm{~F}$ & 18 & YU & TiA16V4 & - & - \\
15 & SOA & $55 \mathrm{~F}$ & 4 & YU & TiA16V4 & - & - \\
Average & & 70 & 15 & & & - \\
\end{tabular}

YU: Yamagata University System; PMMA: polymethyl methacrylate; POA: primary osteoarthritis; SOA: secondary osteoarthritis; TiA16V4: titanium-aluminum-vanadium; CoCrMo: cobalt-chromium-molybdenum.

solution of formalin in phosphate-buffered saline at $4^{\circ} \mathrm{C}$ for $24 \mathrm{~h}$, embedded in paraffin, and cut to $6-\mu \mathrm{m}$ sections, then stained with hematoxylineosin stain for histopathological analysis. Cryostat sections were fixed in acetone for $5 \mathrm{~min}$ at $4{ }^{\circ} \mathrm{C}$ and endogenous peroxidase was blocked with $0.3 \% \mathrm{H}_{2} \mathrm{O}_{2}$ in methanol for $30 \mathrm{~min}$. Sections were treated serially as follows: (1) with normal blocking serum (dilution 1:2; Vector Laboratories, Burlingame, CA, USA) for $1 \mathrm{~h}$; (2) with polyclonal rabbit anti-human TLR 2 IgG ( $2 \mu \mathrm{g} / \mathrm{ml}$; H-175, Santa Cruz Biotechnology, Santa Cruz, CA, USA), rabbit anti-human TLR $4 \mathrm{IgG}(1.3 \mu \mathrm{g} / \mathrm{ml}$; H-80, Santa Cruz Biotechnology), rabbit anti-human TLR 5 IgG $(2 \mu \mathrm{g} / \mathrm{ml}$; H-127, Santa Cruz
Biotechnology), rabbit anti-human TLR $9 \mathrm{IgG}(0.3 \mu \mathrm{g} / \mathrm{ml}$; H-100, Santa Cruz Biotechnology), and/or mouse anti-human CD68 IgG $(2.5 \mu \mathrm{g} / \mathrm{ml}$; Dako Cytomation, Glostrup, Denmark) and mouse anti-human CD15 IgG ( $2.5 \mu \mathrm{g} / \mathrm{ml}$; Santa Cruz Biotechnology); (3) with biotinylated anti-rabbit or mouse $\mathrm{IgG}$, as appropriate; and (4) with avidin-biotin peroxidase complex (Vector Laboratories), for $30 \mathrm{~min}$ each. The sites of peroxidase binding were visualized with a combination of $\mathrm{H}_{2} \mathrm{O}_{2}$ and 3,3-diaminobenzidine tetrahydrochloride (Wako Junyaku, Osaka, Japan) ${ }^{30}$. The sections were counterstained with hematoxylin. Between all steps, sections were washed 3 times with $20 \mathrm{mM}$ Tris- $\mathrm{HCl}$ buffered $150 \mathrm{mM} \mathrm{NaCl}, \mathrm{pH}$ 7.5. The speci- 
Table 2. Profile of infected synovial samples. All cases were diagnosed with secondary osteoarthritis.

\begin{tabular}{|c|c|c|c|c|c|c|c|c|c|}
\hline Case & Age/sex & $\begin{array}{l}\text { Years from THR } \\
\text { to Revision }\end{array}$ & $\begin{array}{c}\text { Type of } \\
\text { Prosthesis }\end{array}$ & Type of Alloy & Wear & $\begin{array}{c}\text { Black } \\
\text { Particles }\end{array}$ & $\begin{array}{l}\text { PMMA } \\
\text { Particles }\end{array}$ & $\begin{array}{c}\text { No. of } \\
\text { Neutrophils } \\
\text { (cells/HPF) }\end{array}$ & Pathogen \\
\hline 2 & $56 \mathrm{~F}$ & 5 & YU & TiA16V4 & - & - & - & $>5$ & SA \\
\hline 3 & $51 \mathrm{M}$ & 4 & YU & TiA16V4 & - & - & - & $>5$ & SE \\
\hline 4 & $79 \mathrm{M}$ & 7 & YU & TiA16V4 & + & - & - & $>5$ & CNS \\
\hline
\end{tabular}

YU: Yamagata University System; THR: total hip arthroplasty; PMMA: polymethyl methacrylate; TiA16V4: titanium-aluminum-vanadium; HPF: high power field; SE: Staph. epidermidis; SA: Staph. aureus; CNS: Coagulase-negative staphylococci; EC: Escherichia coli.

ficity of the staining was tested by using normal rabbit IgG (Jackson Immunoresearch, West Grove, PA, USA) or mouse IgG $(2.5 \mu \mathrm{g} / \mathrm{ml}$, Sigma, St. Louis, MO, USA) at the same concentration instead of the specific primary antibodies. The average number of CD68-positive cells per $/ \mathrm{mm}^{2}$ in 3 random microscopic fields for each section was counted.

Colocalization of TLR was examined using the Alexa fluorescent system (Molecular Probes Inc., Eugene, OR, USA). As a primary antibody, affinity-purified rabbit anti-human TLR 2 IgG, affinity-purified rabbit antihuman TLR 4 IgG, affinity purified rabbit anti-human TLR 5 IgG or goat anti-human TLR 9 IgG (all Santa Cruz Biotechnology); and mouse antihuman CD68 IgG (2.5 $\mu \mathrm{g} / \mathrm{ml}$; Dako) or mouse anti-human CD15 IgG (2.5 $\mu \mathrm{g} / \mathrm{ml}$; Santa Cruz Biotechnology) were all applied at $4 \mu \mathrm{g} / \mathrm{ml}$. For immunofluorescent staining, Alexa Fluor 488-conjugated anti-rabbit or anti-mouse IgG antibodies and Alexa Fluor 546-conjugated anti-goat or anti-rabbit IgG antibodies (Molecular Probes Inc.) were used as recommended by the manufacturer. Samples were observed under a fluorescent microscope (DMLB, DC200, DC viewer software, Leica Microsystems, Wetzlar, Germany). Semiquantitative evaluation of immunohistochemistry was performed to assess the proportion of positively stained area of the total area (scored as: -: no positive staining, \pm : occasional positive cells covering $<5 \%$ of the tissue area examined, + : some positive cells covering $5 \%-25 \%$ of the tissue examined, ++: moderate numbers of positive cells covering $25 \%-50 \%$ of the tissue examined, and +++ : many positive cells covering $>50 \%$ of the tissue examined ${ }^{14}$ ).

Reverse transcriptase polymerase chain reaction (RT-PCR) and quantitative real-time PCR. Extraction of total RNA and RT-PCR. Total RNA isolation, reverse transcription, and PCR amplifications were performed as briefly described below. Total RNA was isolated from $100 \mu \mathrm{g}$ of each tissue with the use of the Isogen kit (Nippongene, Tokyo, Japan). The quantity of total RNA was measured using spectrophotometry at $260 \mathrm{~nm}$. After heating for denaturation at $65^{\circ} \mathrm{C}$ for $5 \mathrm{~min}$, cDNA was produced by reversetranscription followed by incubation in ice for at least $1 \mathrm{~min}$. cDNA Synthesis Mix of $10 \times$ RT buffer $2 \mu l, 25 \mathrm{mM} \mathrm{MgCl}_{2} 4 \mu \mathrm{l}, 0.1$ M DTT $2 \mu \mathrm{l}$,

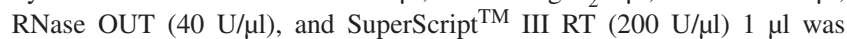
added, followed by incubation at $25^{\circ} \mathrm{C}$ for $10 \mathrm{~min}, 50^{\circ} \mathrm{C}$ for $50 \mathrm{~min}$, and $85^{\circ} \mathrm{C}$ for $5 \mathrm{~min}$ before chilling at $4^{\circ} \mathrm{C}$. Finally, $1 \mu \mathrm{l}$ of RNase $\mathrm{H}$ was added to all samples at $37^{\circ} \mathrm{C}$ for $20 \mathrm{~min}$ (SuperScript ${ }^{\mathrm{TM}}$ III First-Strand Synthesis System for RT-PCR; Invitrogen, Carlsbad, CA, USA) ${ }^{10}$.

Quantitative real-time PCR. Enzymatic amplification of the specific cDNA sequences was performed in LightCycler (Roche Diagnostics, Mannheim, Germany); 5- $\mu$ l aliquots of reverse-transcribed cDNA (diluted 1:10) were subjected to PCR amplification, finally adjusted to $20 \mu \mathrm{l}$ in a solution containing $2 \mathrm{mM} \mathrm{MgCl}_{2}$, and $0.5 \mu \mathrm{M}$ of both forward and reverse primers for TLR 2, 4, 5 and 9. The primers were designed with online software Primer 3 (Whitehead Institute for Biomedical Research, Cambridge, MA, USA) for TLR 2, 4, 5, 9, and $\beta$-actin ${ }^{10,31-33}$ (Table 3). Two microliters of LightCycler Fast Start DNA Master SYBR Green I were also included, which contained Fast Start Taq DNA polymerase, reaction buffer, $200 \mathrm{mM}$
Table 3. Oligonucleotide primers used for PCR and expected template size.

\begin{tabular}{llc}
\hline $\begin{array}{l}\text { Target } \\
\text { Gene }\end{array}$ & $\begin{array}{l}\text { Forward Primer }\left(5^{\prime} \rightarrow 3^{\prime}\right) \\
\text { Reverse Primer }\left(5^{\prime} \rightarrow 3^{\prime}\right)\end{array}$ & $\begin{array}{c}\text { Expected Template } \\
\text { Size (base pair) }\end{array}$ \\
\hline TLR 2 & $\begin{array}{l}\text { GGC CAG CAA ATT ACC TGT GTG } \\
\text { AGG CGG ACA TCC TGA ACC T }\end{array}$ & 69 \\
TLR 4 & $\begin{array}{l}\text { TCC ATA AAA GCC GAA AGG TG } \\
\text { TLR 5 }\end{array}$ & $\begin{array}{l}\text { CTG AGC AGG GTC TTC TCC AC } \\
\text { TGC CTT GAA GCC TTC AGT TAT G }\end{array}$ \\
& $\begin{array}{l}\text { CCA ACC ACC ACC ATG ATG AG } \\
\text { TLR 9 }\end{array}$ & $\begin{array}{l}75 \\
\text { GCT AGA CCT GTC CCG CAA TA }\end{array}$ \\
& $\begin{array}{l}\text { ACA CTT GGC TGT GGA TGT TG } \\
\text { B-actin }\end{array}$ & $\begin{array}{l}\text { TCA CCC ACA CTG TGC CCA TCT ACG A } \\
\text { CAG CGG AAC CGC TCA TTG CCA ATG G }\end{array}$ \\
& CAG CG \\
\hline
\end{tabular}

dNTP mix, SYBR Green I dye, and $1 \mathrm{mM} \mathrm{MgCl} 2$ (Roche Diagnostics). PCR was performed as follows: initial denaturation at $95^{\circ} \mathrm{C}$ for $10 \mathrm{~min}, 40$ cycles of denaturation at $95^{\circ} \mathrm{C}$ for $15 \mathrm{~s}$ each, annealing at $60^{\circ}-62^{\circ} \mathrm{C}$ for $5 \mathrm{~s}$, and extension at $72^{\circ} \mathrm{C}$ for $10 \mathrm{~s}$. PCR products were separated by $2 \%$ agarose gel electrophoresis ${ }^{10,33}$.

Quantitative analysis was performed with LightCycler software (Roche Diagnostics) that detects real-time fluorescent signals that correlate directly to the concentration of the target cDNA. This software performed quantification by comparing the fluorescence of a PCR product of unknown concentration with the fluorescence of several dilutions of a standard; $B$-actin was used as a standard. The ratios of each amplified product to 1000 copies of $\beta$-actin were calculated. All mRNA expression levels were standardized using $\beta$-actin at different concentrations $(10 \mathrm{pg} / \mathrm{ml}, 100 \mathrm{pg} / \mathrm{ml}, 1$ $\mathrm{ng} / \mathrm{ml}$, and $10 \mathrm{ng} / \mathrm{ml}$ ) to serve as a standard ${ }^{10,33}$.

Statistical analysis. The mean and standard error of the mean (SEM) of each standardized mRNA were calculated. Kruskal-Wallis one-way analysis of variance was used for detection of differences among groups. In cases where statistical significance was present, the Mann-Whitney U-test was applied to detect which TLR mRNA expression level was significantly different between aseptic periprosthetic tissues, septic tissues, and OA synovium. A value of $\mathrm{p}<0.05$ was regarded as statistically significant. Pearson's correlation coefficient (r) was also calculated for each standard curve to confirm proper PCR performance with an external standard ${ }^{10,33}$.

\section{RESULTS}

Histopathological examinations. Cell-rich areas in the periprosthetic synovial-like interface membranes around aseptic loosened total hip joints contained mononuclear cells with abundant cytoplasm. Mononuclear CD68-positive 
monocyte/macrophage-like cells formed $70.0 \% \pm 7.2 \%$ of all cells. A few foreign-body giant cells were also seen (Figure 2A). Numerous CD68-positive monocytes/ macrophages were observed in focal stromal cellular infiltrates and in synovial lining, in both the periprosthetic tissues of the interface and regenerated capsules from aseptically loosened hip joints (Figure 3A). Aseptic periprosthetic tissues were also characterized by well organized and often dense fibrous connective tissues (Figure 2A). Polymorphonuclear cells were observed only rarely, although a few scattered CD15+ cells were observed in the synovial lining and sublining layers and in perivascular areas (Figure 3B).

In the septic periprosthetic synovial capsular tissues, stromal fibroblasts and marked cellular infiltration with mononuclear cells were observed, associated with fibrous loose connective tissues and a few neo-vessels (Figure 2B). The infil-
A

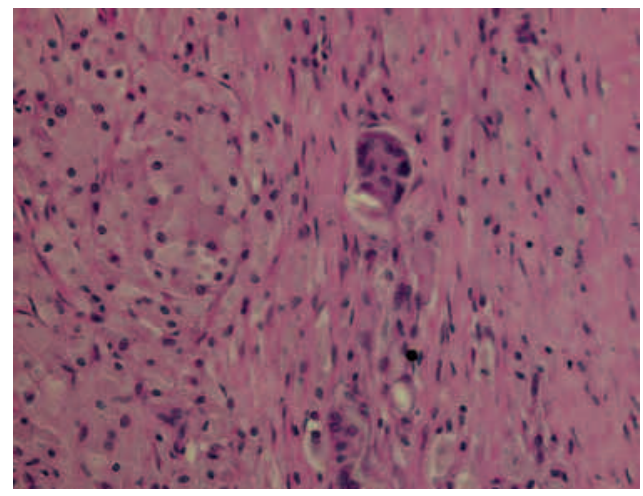

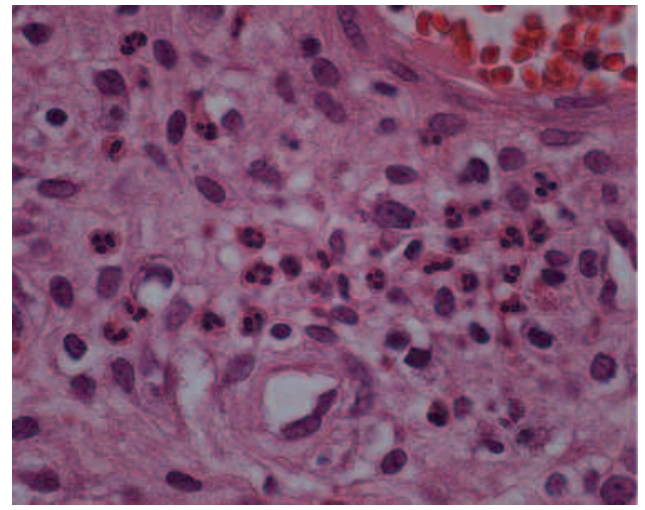

B

Figure 2. Hematoxylin-eosin staining. A. Synovial-like interface membranes and regenerated capsular tissues around socalled aseptic loose/osteolysis hip joints (original magnification $\times 400$ ). A cell-rich area contains mononuclear cells with abundant cytoplasm in synovial-like interface around aseptic loosened total hip joints. B. Polymorphonuclear cells were observed mainly in the synovial membranes around septic hip joints (original magnification $\times 1000$ ).

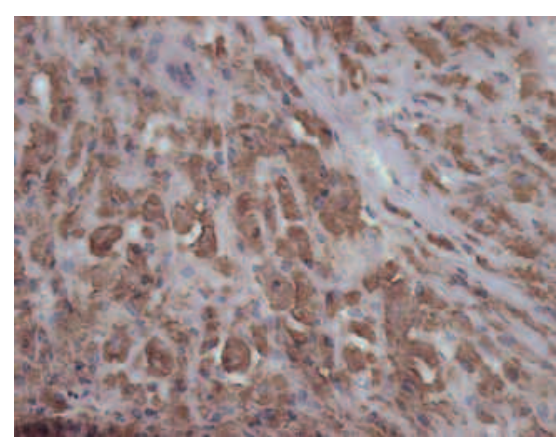

A

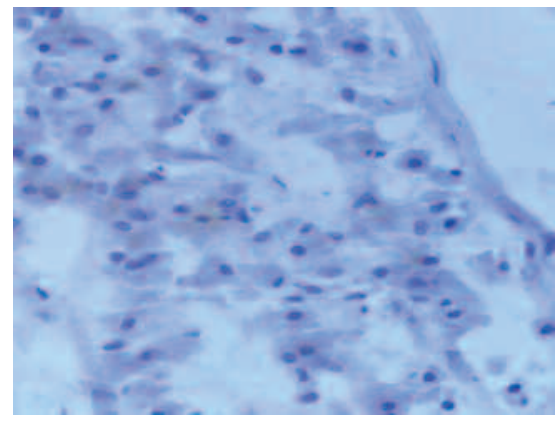

D

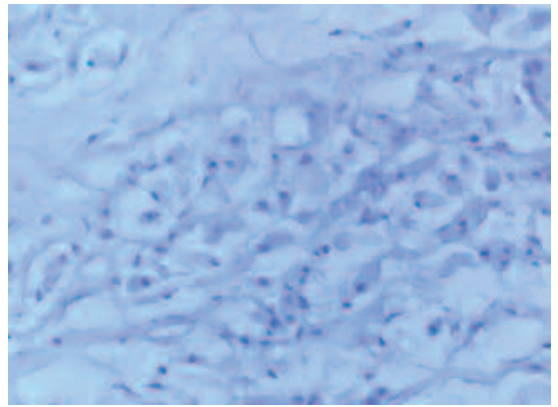

B

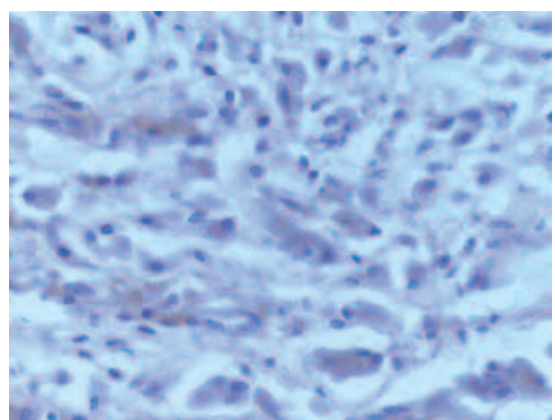

$\mathbf{E}$

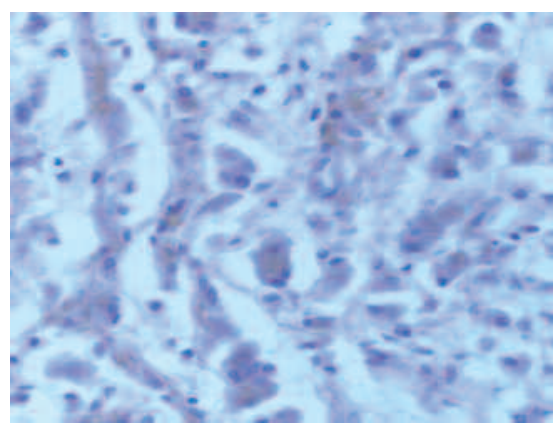

C

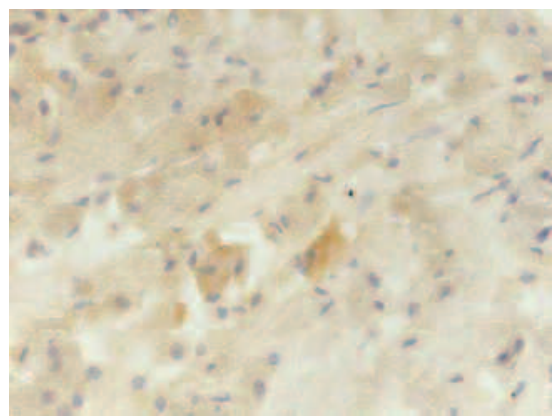

$\mathbf{F}$

Figure 3. CD68-positive cells (A) were observed in focal stromal monocyte/macrophage infiltrates and synovial lining cells in "so-called" aseptic periprosthetic tissues. Immunoreactivity to CD15 (B) was positive in a few scattered polymorphonuclear granulocytes. Negative control staining with nonimmune rabbit IgG proved specificity of the staining. Apart from vascular endothelial cells, TLR 2, 4, 5, and 9 strongly positive mononuclear and multinuclear cells (C, D, E, F) are seen in inflammatory cell infiltrates and in synovial lining cells. 


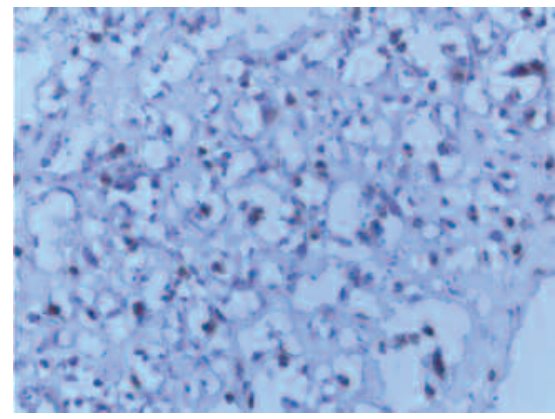

A

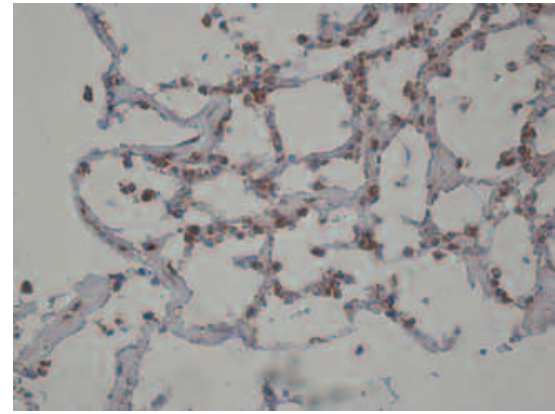

D

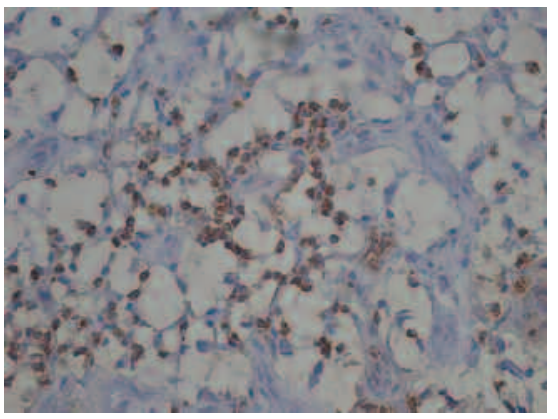

B

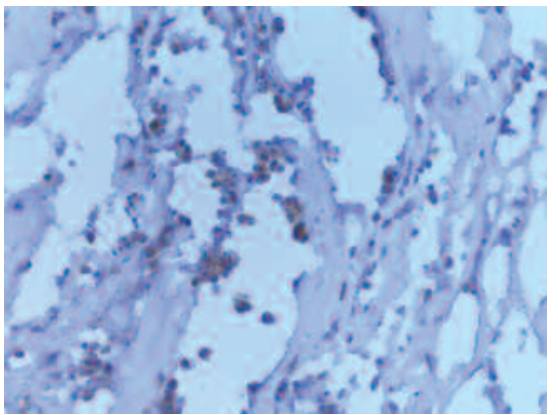

E

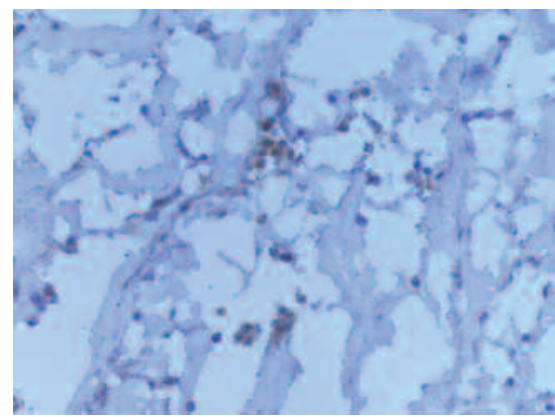

C

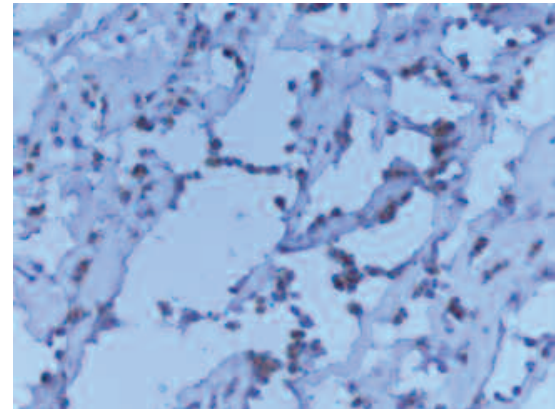

$\mathbf{F}$

Figure 4. CD15-positive cells (A) were mainly observed in synovial membrane around septic artificial joints. Immunoreactivity to CD68 (B) was not observed. Apart from vascular endothelial cells, TLR 2, 4, 5, and 9 strongly positive mononuclear and multinuclear cells (C, D, E, F) are seen in inflammatory cell infiltrates and in synovial lining cells.

A

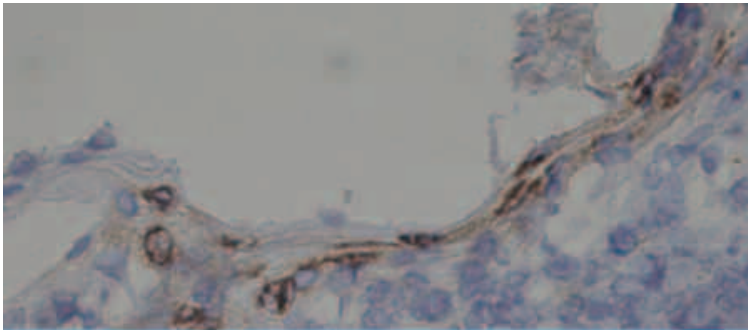

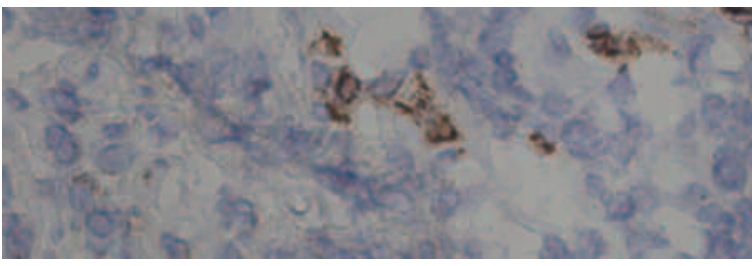

B
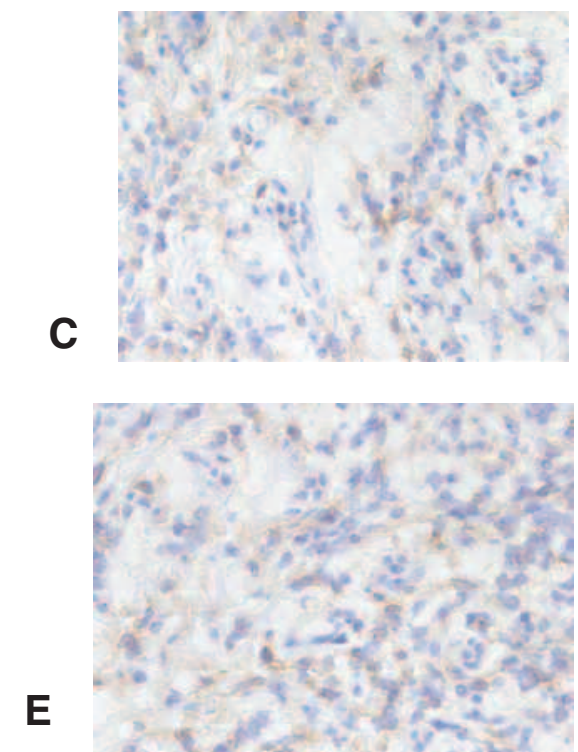

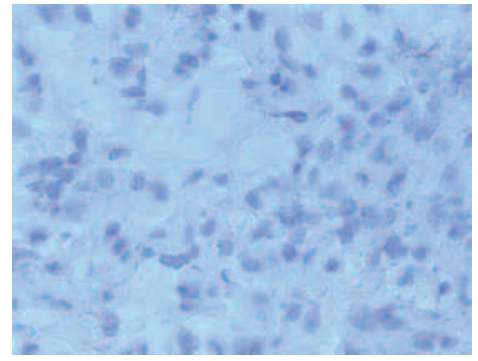

D

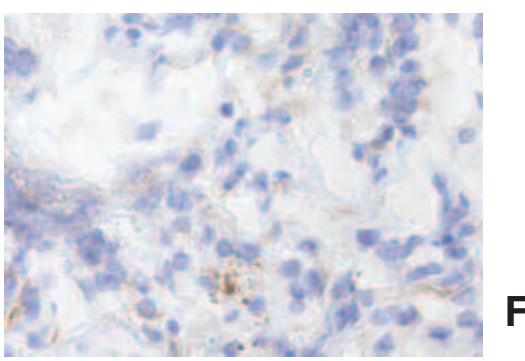

Figure 5. In osteoarthritic synovial membrane a few scattered CD68 (A) and CD15-positive cells (B) were observed in the synovial lining and sublining layers and perivascularly. The most prominent TLR 2, 4, 5, and 9 stainings (C, D, E, F) are seen in the vascular endothelial cells, and occasionally in stromal mononuclear cells and synovial lining cells, which also showed immunoreactivity to CD68 and CD15. Negative control staining with nonimmune rabbit IgG proved specificity of the staining. 
trating cells were mostly polymorphonuclear cells, which were stained with CD15 (Figure 4B). In the synovial tissue samples from OA secondary to dysplasia, no active inflammatory cell infiltrates or lymphoid aggregates were seen, but some mononuclear cell infiltrates and thickening of lining/sublining layers were often observed (Figure 5A, 5B).

All tissue samples from aseptic loosening, septic cases, and OA showed immunoreactivity for TLR 2, 4, 5, and 9. Monocyte/macrophage infiltrates with marked immunoreactivity of TLR 2, 4, 5, and 9 were observed in the synovial lining cells in both the interface and regenerated capsular tissues retrieved from aseptically loosened hip joints (Figure 3C, 3D, 3E, 3F). In the septic tissues, immunoreactivity to TLR 2, 4, 5, and 9 was detectable in polymorphonuclear cell infiltrates and in those few monocytes/macrophage-like cells that were also present (Figure 4C, 4D, 4E, 4F). In contrast, in OA only modest reactivity to TLR $2,4,5$, and 9 was seen in the endothelial cells and synovial lining (Figure 5C, $5 \mathrm{D}, 5 \mathrm{E}, 5 \mathrm{~F})$. The negative control staining with nonimmune rabbit IgG proved the specificity of the staining (data not shown).

Double-immunofluorescent staining was also performed in the aseptic, septic, and OA tissue samples. Colocalization of CD68/TLR 2, 4, 5, and 9 was seen in the focal monocyte/macrophage aggregates and synovial lining cells in the periprosthetic tissues of the interface and regenerated capsules around aseptic total hip joints (Figure 6A, 6B, 6C). In the septic synovial membranes, colocalization of CD15/TLR $2,4,5$, and 9 was mainly seen in polymorphonuclear cells (Figure 7A, 7B, 7C). In OA, immunoreactivity for TLR 2, 4, 5, and 9 and CD68 was seen in monocytes/macrophages (Table 4). Autofluorescence and nonspecific background were found to only a minor degree and they did not interfere with the visualization of specific staining.

Quantitative real-time PCR. Melting-curve analysis showed that the peaks on curves represented the melting temperatures. In melting-curve analysis, all TLR and $\beta$-actin we examined showed only a single peak, confirming accurate PCR performance without nonspecific products. Pearson's correlation coefficients (r) of these curves were $<0.995$, confirming accurate PCR amplification. Quantification curves showed the fluorescence data acquired once per cycle, displaying fluorescence versus cycle number. The values of target mRNA expression were calculated by linear regression of standard curve in these quantification analyses. mRNA levels of TLR 2, 4, 5, and 9 in the aseptic and septic periprosthetic tissues were higher than those of OA synovial tissues. The ratio of TLR 2/1000 copies of $\beta$-actin was $7.10 \pm 0.63$ in aseptic tissues, $6.60 \pm 0.83$ in the septic tissues, and $0.68 \pm$ 0.47 in OA tissues (aseptic and septic vs OA; $p<0.0001$; Figure $8 \mathrm{~A}]$. The ratios of TLR 4/1000 copies of $B$-actin were $0.26 \pm 0.11$ in aseptic tissues, $0.18 \pm 0.12$ in septic tissues, and $0.04 \pm 0.03$ in OA tissues (aseptic vs OA, p $<0.0001$; and septic vs OA, $\mathrm{p}=0.0017$; Figure 8B). The ratios of TLR
Table 4. Immunohistochemical profile of the tissue samples.

\begin{tabular}{lccc}
\hline & Aseptic & Septic & Osteoarthritis \\
\hline Localization & & & \\
CD68 & +++ & $\pm \sim+$ & \pm \\
CD15 & - & $+\sim++$ & \pm \\
Colocalization & & & \\
TLR2 & & & - \\
CD68 & + & + & - \\
CD15 & - & + & - \\
TLR4 & & & - \\
CD68 & + & + & - \\
CD15 & - & + & - \\
TLR 5 & & & - \\
CD68 & + & + & - \\
CD15 & - & + & \\
TLR9 & & + & + \\
CD68 & - & & + \\
CD15 & & & \\
\hline
\end{tabular}

Scored as: -: no positive staining, \pm : occasional positive cells covering $<5 \%$ of the tissue area examined, + : some positive cells covering $5 \%-25 \%$ of the tissue examined, ++: moderate numbers of positive cells covering $25 \%-50 \%$ of the tissue examined, and +++ : many positive cells covering $>50 \%$ of the tissue examined ${ }^{14}$.

$5 / 1000$ copies of $\beta$-actin in each tissue were $3.24 \pm 0.81$ in aseptic tissues, $3.00 \pm 0.84$ in septic tissues, and $0.31 \pm 0.19$ in OA tissues (aseptic and septic vs OA, $\mathrm{p}<0.0001$; Figure $8 C$ ). The ratios of TLR $9 / 1000$ copies of $\beta$-actin were $0.29 \pm$ 0.02 in aseptic tissues, $0.25 \pm 0.05$ in septic tissues, and 0.01 \pm 0.01 in OA tissues (aseptic and septic vs OA, $p<0.0001$; Figure 8D). In addition, the ratios of TLR 2 and 5 per 1000 copies of $B$-actin were higher than those of TLR 4 and 9 in both aseptic and septic tissues (aseptic and septic vs OA, $\mathrm{p}<0.001)$.

\section{DISCUSSION}

In our study, infiltrative CD68+ monocytes/macrophages of aseptic loose tissues were positive for TLR 2, 4, 5, and 9. In addition, in septic loosening, CD15+ polymorphonuclear cells were also positive for TLR 2, 4, 5, and 9. In spite of this difference in the cell profile between aseptic and septic cases, both contain high numbers of cells able to sense danger with increased level of mRNA coding for these TLR proteins. The difference between these 2 different conditions to OA was very clear.

TLR ligands enhance the nuclear factor- $\mathrm{KB}(\mathrm{NF}-\kappa \mathrm{B})$ signal transduction pathway and thus induce enhanced production of osteolytic inflammatory cytokines and extracellular matrix-degrading proteinases ${ }^{34-38}$. Thus, the presence of TLR in both aseptic and septic loosening, together with reports, 5,13 of the presence of cytokines and matrix-degrading enzymes in such tissues, seems to support the contribution of such molecules to the pathogenesis of 2 different modes of loosening, where the monocytes/macrophages seem to play a dominant role in aseptic loosening, whereas

$$
\text { Personal non-commercial use only. The Journal of Rheumatology Copyright @ } 2009 \text {. All rights reserved. }
$$




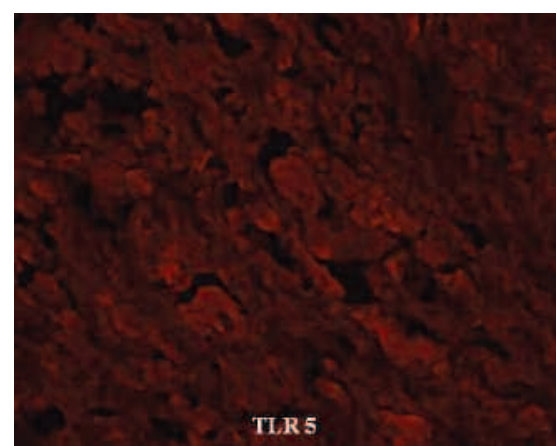

A

Figure 6. Colocalization of TLR 5 and CD68. TLR 5 stained red using Alexa Fluor 546 (A); CD68 stained green using Alexa Fluor 488 (B). A combination of TLR and CD68 shows as yellow-green (C). Immunofluorescent double-staining indicated monocytes/macrophages as the main TLR-positive cells in the synovial-like interface membrane around aseptic loose hip joints.

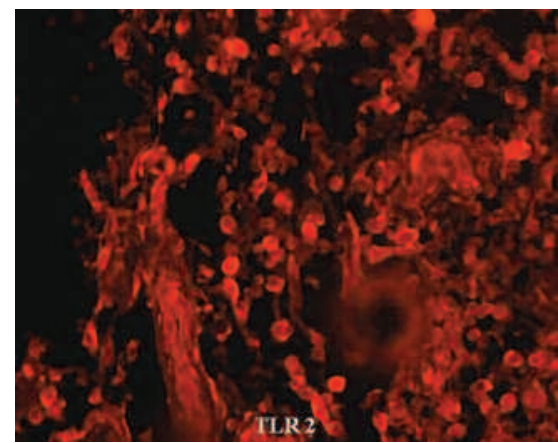

A

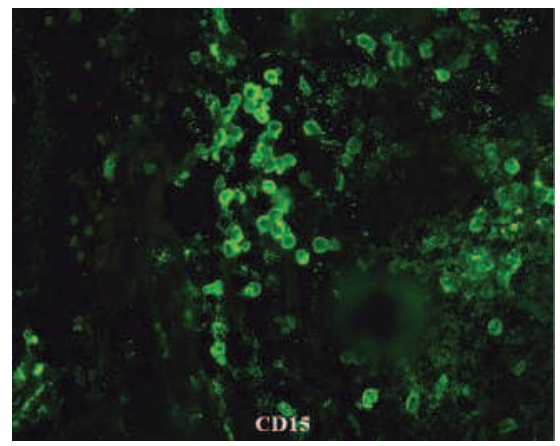

B

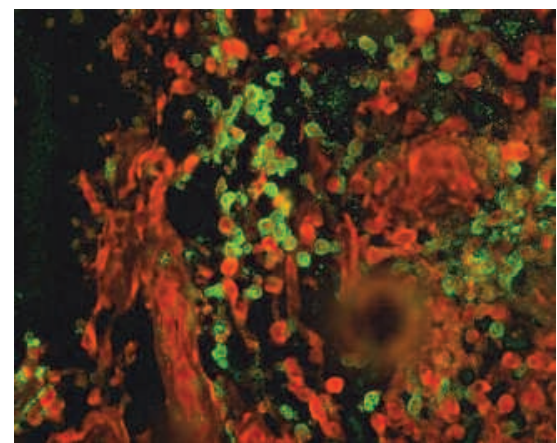

C

Figure 7. Colocalization of TLR 2 and CD15. TLR stained red using Alexa Fluor 546 (A); CD15 stained green using Alexa Fluor 488 (B). A combination of TLR 2 and CD15 shows as yellow-green (C). Immunofluorescent double-staining indicated monocytes/macrophages as the main TLR-positive cells in the synovial membrane around septic loose hip joints.

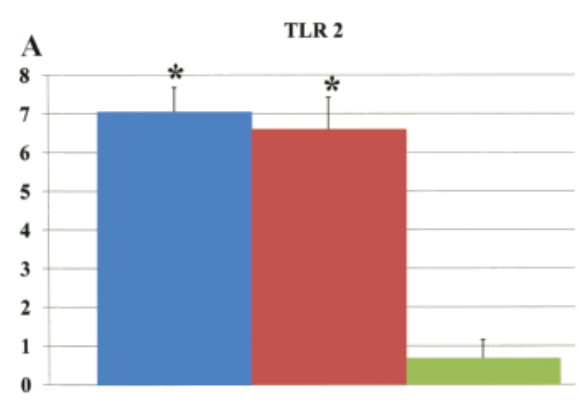

Aseptic $=$ Septic $=\mathbf{O A}$

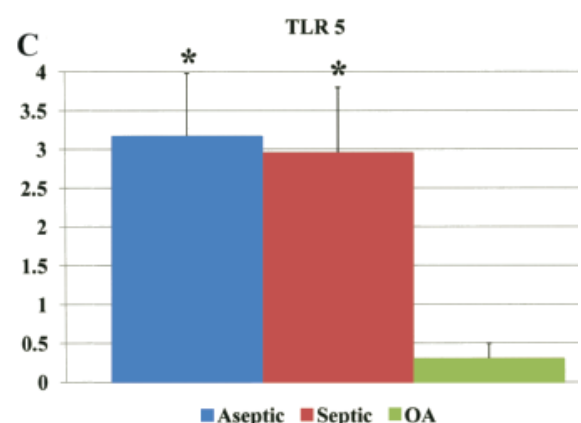

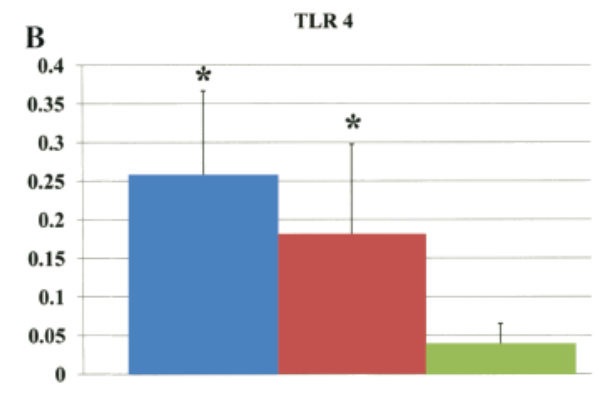

- Aseptic $=$ Septic $=\mathbf{O A}$

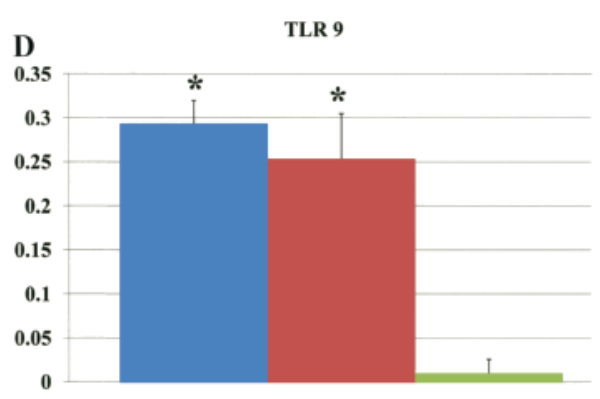

Aseptic $=$ Septic $=\mathbf{O A}$

Figure 8. Quantitative real-time PCR analysis showed mRNA expression levels of TLR 2 (A), TLR 4 (B), TLR 5 (C), and TLR 9 (D). Data are ratios of aseptic and septic tissues around artificial hip joints compared to osteoarthritic tissues. *All p $<0.05$. 
TLR-equipped polymorphonuclear leukocytes predominate in septic loosening (Figures 1 and 9).

Our recent study ${ }^{14}$ demonstrated immunohistochemical localization of TLR 4 and 9 in the periprosthetic tissues of synovial-like interface membrane around aseptically loosened THR implants. The current study extends the description of the TLR profile in aseptic loosening to septic cases as well. In the previous in vitro experiments, mRNA expression of TLR 4 and 9 in macrophages was first rapidly upregulated by particle stimulation in vitro, followed by rapid and effective downregulation ${ }^{14}$. These data imply that the TLR-related signal pathway is tightly self-regulated to prevent excessive and harmful host responses, including injury to innocent bystander cells/tissues. It also indicates that the turnover of monocyte/macrophages must be very rapid in periprosthetic tissues, as these cells in the interface membrane are strongly positive. We concluded that they represent newly recruited cells that have not yet undergone TLR downregulation. This could also apply to polymorphonuclear leukocytes, as they only survive for 1-3 days once they have left the intravascular compartment and have transmigrated through the epithelium to periprosthetic tissues ${ }^{39}$. Immunoreactivities to TLR 2, 4, 5, and 9 were well detected in periprosthetic tissues around both aseptic and septic total hip joints. In contrast, mRNA analysis showed higher expression of TLR 2 and 5 than of TLR 4 and 9. Although the explanation for the discrepancy of the in loco status is unclear, it may be explained by the possibility of a different translation mechanism from mRNA to corresponding protein, or a different afferent affinity of antibodies used in the study. Further analysis by more refined methods would be required to address this issue.

It remains unknown if the local TLR in periprosthetic tissues are engaged in ligand recognition and binding. In aseptic loosening this seems somewhat unlikely at first, because by definition these cases contain no living microbes. Two lines of evidence indicate that such TLR engagement may still be possible. First, recent studies in which sonication has been used to collect samples from implants for microbial cultures suggest that in many cases in which conventional microbial cultures have been negative, some living bacteria can be found ${ }^{40,41}$. This suggests that some of the implantassociated bacteria may be hidden in biofilms and are not easily observed using conventional microbial sampling methods. If such dormant bacterial localization relates to enhanced expression of TLR in periprosthetic tissues, precise analyses of the tissues, combined with bacterial separation and the ligand recognition-binding assay and more refined techniques, may reveal the status of low virulent and/or symbiotic microbial localization in the periprosthetic tissues of so-called "aseptic" loosening. This may contribute to the differential diagnosis of uncertain cases. Second, in addition to microbial PAMP, endogenous ligands for TLR have also been recently verified. The best known example is monosodium urate, which is released from dying cells and in the extracellular milieu crystallizes and becomes able to bind to TLR, leading to cellular activation ${ }^{42,43}$. Thus, TLR ligands have expanded from the original exogenous PAMP to endogenous alarmins, which together form alarmins or "danger signals" 22 . They are both able to cause robust

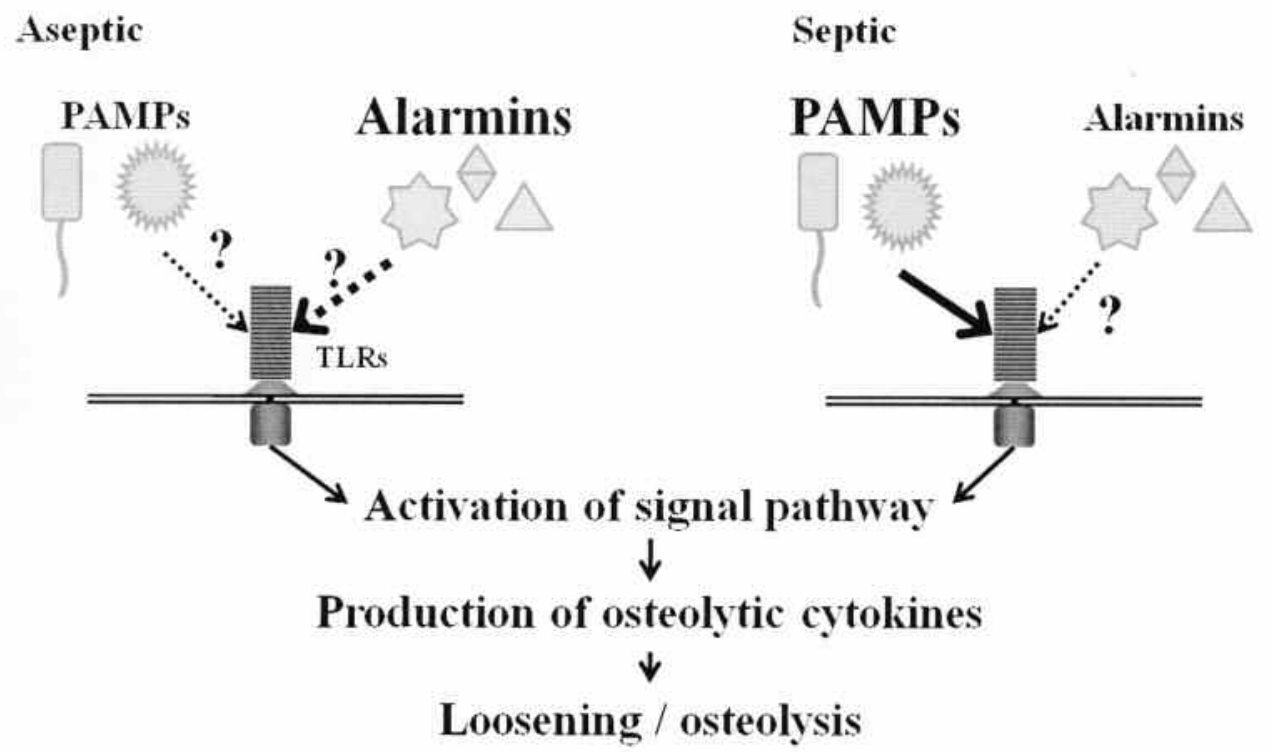

Figure 9. Possible relationships among TLR and their ligands in periprosthetic host responses. Periprosthetic tissues on artificial hip joints are constantly influenced by exogenous PAMP and endogenous alarmins. In aseptic loosening/osteolysis, exogenous PAMP and endogenous alarmins in the periprosthetic microenvironment have potential to be recognized by TLR. In septic loosening/osteolysis, exogenous PAMP may be recognized by TLR. Recognition of these ligands may stimulate intracellular signaling pathways. By activation of the signal pathway, osteolytic cytokines and extracellular matrix-degrading proteinases may be produced by this cascade. 
inflammation, which is usually rapidly downregulated as the inflammatory host defense is taken over by the slower, but more sophisticated and specific adaptive immune responses. From this point of view, the TLR armamentarium of periprosthetic tissues might also contribute to delayed cell-mediated immunity in, for example, metal-on-metal implants, which often contain high concentrations of metal ions in periprosthetic tissues, due to electrochemical corrosion of the implants and implant-derived metallic nanoparticles (Figure 9).

In conclusion, increased expression of TLR was found in the synovial-like interfacial membrane in aseptic periprosthetic and septic synovial cases compared to osteoarthritic tissues. The association of the monocyte/macrophage and neutrophil-associated TLR with the periprosthetic inflammation remains speculative, but likely, as both endogenous alarmins (formed as a result, for example, of cellular necrosis) and exogenous live or dead PAMP can act as potent stimuli. Future studies are needed to determine if the local cells show signs of TLR ligand-driven cellular processes, and if such processes in tissue explants can be inhibited by blocking the TLR-mediated signaling pathways.

\section{ACKNOWLEDGMENT}

We sincerely thank Eiko Saito for her skilful technical support in immunohistochemistry.

\section{REFERENCES}

1. Goodman SB, Huie P, Song Y, et al. Loosening and osteolysis of cemented joint arthroplasties. A biologic spectrum. Clin Orthop Relat Res 1997;337:149-63.

2. Farber A, Chin R, Song Y, Huie P, Goodman S. Chronic antigen-specific immune-system activation may potentially be involved in the loosening of cemented acetabular components. J Biomed Mater Res 2001;55:433-41.

3. Arora A, Song Y, Chun L, et al. The role of the TH1 and TH2 immune responses in loosening and osteolysis of cemented total hip replacements. J Biomed Mater Res A 2003;64:693-7.

4. Harris WH, Schiller AL, Scholler JM, Freiberg RA, Scott R. Extensive localized bone resorption in the femur following total hip replacement. J Bone Joint Surg Am 1976;58:612-8.

5. Konttinen YT, Takagi M, Mandelin J, et al. Acid attack and cathepsin $\mathrm{K}$ in bone resorption around total hip replacement prosthesis. J Bone Miner Res 2001;16:1780-6.

6. Takagi M, Santavirta S, Ida H, et al. High turnover periprosthetic bone remodeling and immature bone formation around loose cemented total hip joints. J Bone Miner Res 2001;16:79-88.

7. Santavirta S, Konttinen YT, Bergroth V, Eskola A, Tallroth K, Lindholm TS. Aggressive granulomatous lesions associated with hip arthroplasty. Immunopathological studies. J Bone Joint Surg Am 1990;72:252-8.

8. Takagi M. Neutral proteinases and their inhibitors in the loosening of total hip prostheses. Acta Orthop Scand Suppl 1996;271:3-29.

9. Takagi M, Santavirta S, Ida H, Ishii M, Mandelin J, Konttinen YT. Matrix metalloproteinases and tissue inhibitors of metalloproteinases in loose artificial hip joints. Clin Orthop Relat Res 1998;352:35-45.

10. Sasaki K, Takagi M, Mandelin J, et al. Quantitative analysis of mRNA expression of TIMPs in the periprosthetic interface tissue of loose hips by real-time PCR system. J Biomed Mater Res 2001;58:605-12.
11. Kim KJ, Rubash HE, Wilson SC, D'Antonio JA, McClain EJ. A histological and biochemical comparison of the interface tissues in cementless and cemented hip prostheses. Clin Orthop Relat Res 1993;287:142-52.

12. Kim KJ, Chiba J, Rubash HE. In vivo and in vitro analysis of membranes from hip prostheses inserted without cement. J Bone Joint Surg Am 1994;76:172-80.

13. Takei I, Takagi M, Ida H, Ogino T, Santavirta S, Konttinen YT. High macrophage-colony stimulating factor levels in synovial fluid of loose artificial hip joints. J Rheumatol 2001;27:894-9.

14. Takagi M, Tamaki Y, Hasegawa H, et al. Toll-like receptors in the interface membrane around loosening total hip replacement implants. J Biomed Mater Res A 2007;81:1017-26.

15. Goodman SB, Gomez-Barrena E, Konttinen YT, Takagi M. Biocompatibility of total joint replacements: a review. J Biomed Mater Res A 2008 May 28. Epub ahead of print.

16. Akira S, Takeda K, Kaisho T. Toll-like receptors: critical proteins linking innate and acquired immunity. Nat Immunol 2001;2:675-80.

17. Takeda K, Akira S. Toll-like receptors in innate immunity. Int Immunol 2005;17:1-14.

18. Kawai T, Akira S. TLR signaling. Cell Death Differ 2006;13:816-25.

19. Hashimoto C, Hudson KL, Anderson KV. The Toll gene of Drosophila, required for dorsal-ventral embryonic polarity, appears to encode a transmembrane protein. Cell 1988;52:269-79.

20. Lemaitre B, Nicolas E, Michaut L, Reichhart JM, Hoffmann JA. The dorsoventral regulatory gene cassette spatzle/Toll/cactus controls the potent antifungal response in Drosophila adults. Cell 1996;86:973-83.

21. Medzhitov R, Preston-Hurlburt P, Janeway CA Jr. A human homologue of the Drosophila Toll protein signals activation of adaptive immunity. Nature 1997;388:394-7.

22. Bianchi ME. DAMPs, PAMPs and alarmins: all we need to know about danger. J Leukoc Biol 2007;81:1-5.

23. Aderem A, Ulevitch RJ. Toll-like receptors in the induction of the innate immune response. Nature 2000;406:782-7.

24. Janeway CA Jr, Medzhitov R. Innate immune recognition. Annu Rev Immunol 2002;20:197-216.

25. Akira S, Hemmi H. Recognition of pathogen-associated molecular patterns by TLR family. Immunol Lett 2003;85:85-95.

26. O'Neill LA, Fitzgerald KA, Bowie AG. The Toll-IL-1 receptor adaptor family grows to five members. Trends Immunol 2003;24:286-90.

27. Takeuchi O, Akira S. Toll-like receptors; their physiological role and signal transduction system. Int Immunopharmacol 2001;1:625-35.

28. Takeda K, Akira S. Roles of Toll-like receptors in innate immune responses. Genes Cells 2001;6:733-42.

29. Zimmerli W, Trampuz A, Ochsner PE. Prosthetic-joint infections. N Engl J Med 2004;351:1645-54.

30. Hsu SM, Raine L, Fanger H. Use of avidin-biotin-peroxidase complex $(\mathrm{ABC})$ in immunoperoxidase techniques: a comparison between $\mathrm{ABC}$ and unlabeled antibody (PAP) procedure. J Histochem Cytochem 1981;29:577-80.

31. Takei I, Takagi M, Santavirta S, et al. Messenger ribonucleic acid expression of 16 matrix metalloproteinases in bone-implant interface tissues of loose artificial hip joints. J Biomed Mater Res 2000;52:613-20.

32. Zarember KA, Godowski PJ. Tissue expression of human Toll-like receptors and differential regulation of Toll-like receptor mRNAs in leukocytes in response to microbes, their products, and cytokines. J Immunol 2002;168:554-61.

33. Tamaki Y, Sasaki K, Sasaki A, et al. Enhanced osteolytic potential of monocytes/macrophages derived from bone marrow after 
particle stimulation. J Biomed Mater Res Part B: Appl Biomater 2008;84:191-204.

34. Kyburz D, Rethage J, Seibl R, et al. Bacterial peptidoglycans but not $\mathrm{CpG}$ oligodeoxynucleotides activate synovial fibroblasts by tolllike receptor signaling. Arthritis Rheum 2003;48:642-50.

35. Radstake TR, Roelofs MF, Jenniskens YM, et al. Expression of toll-like receptors 2 and 4 in rheumatoid synovial tissue and regulation by proinflammatory cytokines interleukin- 12 and interleukin-18 via interferon-gamma. Arthritis Rheum 2004;50:3856-65.

36. Pierer M, Rethage J, Seibl R, et al. Chemokine secretion of rheumatoid arthritis synovial fibroblasts stimulated by Toll-like receptor 2 ligands. J Immunol 2004;172:1256-65.

37. Brentano F, Schorr O, Gay RE, Gay S, Kyburz D. RNA released from necrotic synovial fluid cells activates rheumatoid arthritis synovial fibroblasts via Toll-like receptor 3. Arthritis Rheum 2005;52:2656-65.

38. Caron G, Duluc D, Frémaux I, et al. Direct stimulation of human T cells via TLR5 and TLR7/8: flagellin and R-848 up-regulate proliferation and IFN-gamma production by memory CD4+ T cells. J Immunol 2005;175:1551-7.

39. Bainton DF. Neutrophil granules. Br J Haematol 1975;29:17-22.

40. Trampuz A, Piper KE, Jacobson MJ, et al. Sonication of removed hip and knee prostheses for diagnosis of infection. N Engl J Med 2007;357:654-63

41. Esteban J, Gomez-Barrena E, Cordero J, Martín-de-Hijas NZ, Kinnari TJ, Fernandez-Roblas R. Evaluation of quantitative analysis of cultures from sonicated retrieved orthopedic implants in diagnosis of orthopedic infection. J Clin Microbiol 2008;46:488-92.

42. Shi Y, Evans JE, Rock KL. Molecular identification of a danger signal that alerts the immune system to dying cells. Nature 2003;425:516-21.

43. Liu-Bryan R, Scott P, Sydlaske A, Rose DM, Terkeltaub R. Innate immunity conferred by Toll-like receptors 2 and 4 and myeloid differentiation factor 88 expression is pivotal to monosodium urate monohydrate crystal-induced inflammation. Arthritis Rheum 2005;52:2936-46. 